\title{
An Analysis of the Relationship between Regulatory Control and Corruption based on Product and Market Regulation and Corruption Perceptions Indices
}

\author{
Bahaudin G. Mujtaba, D.B.A. \\ Professor, Nova Southeastern University, USA \\ Bob McClelland
}

$\mathrm{PhD}$, Professor of Marketing, Liverpool John Moores University, UK; Head of the Management Department at Centre for Commerce and Management RMIT, Vietnam

\section{Peter Williamson}

$\mathrm{PhD}$, Professor of Marketing, Liverpool John Moores University, UK; external examiner with Teesside University, and the University of Staffordshire, UK; a visiting Professor in Marketing at the Institute of International Studies, Ramkhamhaeng University, Thailand

\section{Nile Khanfar}

$\mathrm{PhD}$, Associate Professor in the Sociobehavioral and Administrative Pharmacy Department, Nova Southeastern University College of Pharmacy, USA

Frank J. Cavico, J.D.

Professor, Nova Southeastern University, USA

\begin{abstract}
This paper focuses on the relationship between two important business indices: the degree to which a country's business is centrally regulated, and the level of business corruption perceived in that country. The main purpose and methodology is to analyze the data from 47 globally dispersed countries based on the Organization for Economic Co-operation and Development (OECD) Product and Market Regulation Index and Transparency International's Corruption Perceptions Index from 2013. The statistical methodology using regression analysis demonstrates that there is a significant negative relationship between levels of perceived corruption and levels of regulation. This paper empirically confirms that corruption tends to increase with low levels of regulations. The results of this study can be useful for policy makers, managers, and research; as such, the authors provide appropriate recommendations for policy-makers and business leaders. While there are examples from several countries in this paper, the authors provide many sources and literature from the United States as most readers can easily relate to them. The limitations of the study and suggestions for future research are also stated.

Overall, the findings of this study show that more product market regulation is a significant factor in demonstrating less perceived corruption for the 47 countries selected for this research. Our results demonstrate that countries with high levels of regulation have low perceived levels of corruption. In this focused empirical study, the authors found that more regulation is associated with less perceived corruption. So, what explanations might be advanced? Perhaps the answer lies in the ability of business regulation to actually make a difference in the level of corruption, even presuming there is a desire to do so. If we assume it is desirable to reduce the level of corporate corruption, and that one of the mechanisms to achieve this objective is through sensible business regulation, this study has demonstrated that countries with high levels of regulation seems to have low perceived levels of corruption.
\end{abstract}

Keywords: corruption perceptions, regulation, product market regulation, OECD Product, CPI, poverty.

JEL Classification: D73, L51, M31, I32.

(C) The Authors, 2018. This article is published with open access at Sumy State University.

\section{Introduction}

It has been said: "Not one single country, anywhere in the world, is corruption free" (Ugaz, 2015: 2). Sadly, in some regions, "long-standing corruption has led to a desperate lack of investment in security, education and health. Until these weaknesses are addressed, corruption will continue to be the norm and citizens' quality of 
life will not improve" (Salas, 2015: 9). As such, proper regulations can be used to address security, education, environmental, and health problems in proactively curbing corruption.

Corruption is a worldwide problem for all public sector officials and governments (Huang, Mujtaba, Cavico, and Sims, 2006). Therefore, a principal challenge for business leaders today is to efficiently and effectively deal with the many government regulations imposed on business to reduce the temptation toward corruption (Cavico, 2014; Mujtaba, Williamson, Cavico, and McClelland, 2013; Mujtaba, McClelland, Cavico, Williamson, 2013). This task is even more burdensome and challenging since some rules mandate certain conduct toward doing what is legally right for all stakeholders; yet certain formal and informal structures tend to discourage risk-taking and innovation that may run afoul of a regulatory scheme (Ikwukananne and Mujtaba, 2013; Mujtaba, 2014). As such, a concomitant challenge for government leaders is to strike the right balance between regulation and entrepreneurship and innovation, so as to motivate business people to obey the law and avoid corruption, yet without stifling business creativity, research, and development.

For example, in the United States, the daily news is replete with stories of the Donald Trump Administration's "tough talk" to friends and foes alike; but also in the context herein is the vow to reduce government regulations, as clearly reflected in the campaign slogans and promises, in order to make U.S. firms more competitive and profitable (Goodman, Gough, Wee and Ewig, 2017). Some of the harsh rhetoric toward refugees linked to the so-called "Muslim Ban" has increased discrimination toward Americans who look Middle Eastern (Mujtaba, Cavico and Senathip, 2016). Consequently, now, the administration is relaxing some of the previously agreed upon rules and regulations that applied to small and large businesses. Furthermore, during his first two weeks as President, in January 2017, President Trump signed an Executive Order to freeze or stop the hiring of new employees in most federal government agencies.

To compare with another economically influential country due to its population, in India, as a part of the campaign promise of fighting corruption by cutting tax evasion and recovering illegal income, the government has decided on more regulation. To illustrate, the Indian Prime Minister, Narendra Modi vowed to omit the 500 and 1,000 Rupee notes. The same move is considered by the European Central Bank, which is seriously thinking of discontinuing the use of the 500-Euro note in a process that aims to stop their use in "illicit activities." As a part of the public's response in India to this decision, many Indian people rushed to banks to withdraw their savings and to buy gold instead (Singh, 2016). Mr. Modi's decision was met with criticism from many analysts. According to Manish Kejriwal, founder of Kedaara Capital Advisors, a Mumbai private equity firm, this government decision can have several drawbacks, especially adversely affecting the real estate, gold, and other luxury market items. Kejriwal also anticipates a dramatic drop of their prices (Anand \& Kumar, 2016). According to Plipat (2015: 11):

In India and Sri Lanka leaders are falling short of their bold promises, while governments in Bangladesh and Cambodia are exacerbating corruption by clamping down on civil society. In Afghanistan and Pakistan, a failure to tackle corruption is feeding ongoing vicious conflicts, while China's prosecutorial approach isn't bringing sustainable remedy to the menace. This inability to tackle root causes holds true across the region - witness, for example, Australia's dwindling score in recent years.

In the same effort to curb corruption of tax evasion, in 2010, the U.S. Congress enacted the Foreign Accounts Tax Compliance Act known as (FATCA), which required U.S. citizens and lawful residents to report to the Department of Treasury by means of electronic filing, any holdings in foreign bank and financial accounts (FBAR) worth above U.S. \$10,000. Reports should include bank accounts, brokerage accounts, mutual funds, trusts, or other types of foreign financial accounts with balances that exceed certain thresholds. Moreover, apart from the US, the law applies to persons, entities, including but not limited to corporations, partnerships, or limited liability companies, established or managed in the U.S. or formed under the laws and regulations of the USA (Barker, 2016). Relevant to this implementation, UBS AG, which is a Swiss global financial services company, provides wealth management, asset management, and investment banking services for private, corporate, and institutional clients worldwide, and is generally considered to be a "bulge bracket" bank (UBS, 2016). The company found itself in major conflict with the U.S. Internal Revenue Service (IRS) and Justice Department for not releasing secret accounts information for US citizens demanded by the US government. Subsequently, UBS released thousands of voluntary disclosures to the IRS. Ultimately, the Swiss Parliament passed a law allowing banks to reveal client identities to U.S. authorities, so long as they were not violating Swiss bank-secrecy laws. In 2009, UBS paid the U.S. \$780 million to settle charges that it facilitated wealthy Americans avoid taxes (Wood, Beware More FBAR And FATCA Reporting Changes, 2016).

Another controversial law passed in 28 of the states in the U.S., including the District of Columbia, is the law that allows medical cannabis for the treatment of patients who hold documents or statements from their 
physician indicating those patients, for example, cancer patients, might benefit from the medical cannabis. Each of the 28 states has its own approved conditions and criteria for the cultivation and possession of the product and for the treatment of eligible patients (ProCon, 2016). The Office of National Drug Control Policy, however, opposes further legalization of marijuana and other drugs because legalization would, it is feared, upsurge the obtainability and usage of unlawful drugs, and consequently pose substantial health and safety hazards to all people, but mainly young people (Office of National Drug Control, 2012). The Federal Drug Administration finds that cannabis does not meet the criteria for accepted medical use due to lack of evidence regarding safety and the high risk of abuse (DEA, 2016). The growth of medical marijuana laws in the U.S. has led to a paradoxical situation with a new form of entrepreneurship being created as well as a heavily regulated industry. Whether the government regulation will be sufficient to prevent abuse and corruption in the marijuana business, which is still a large cash business due to the fact that the product is still being regarded as an illegal drug on the federal level in the U.S., remains to be seen. The dichotomy of a product being illegal on the national level but legal on some state levels in the U.S. is a result of the U.S. being a federal political system, with a national government, called the "federal" government, and constituent government elements, in the U.S. called states. Russia and Mexico are also federal systems; and, as a matter of fact, in Mexico the constituent government elements are also called "states" and Mexico, like the District of Columbia in the U.S., has a federal government district in Mexico City.

\section{Political Systems and Regulations}

Political systems and regulations tend to go hand-and-hand. As such, before one can discuss the impact of regulations and corruption on a country and any relationship among the two, an awareness of the political system of the region and nation initially should be understood. Data shows that over 500,000 Vietnamese became refugees in the United States after the Americans left Vietnam in the 1970s; and as of 2013, there are around 1.8 million Vietnamese-Americans, which figure represents a fairly small percentage of its total population of 328 million Americans. Sadly, there are over 5 million Syrian refugees in the Middle East, and the U.S. government should act responsibly to help them resettle and rebuild their lives in various countries around the world, including cities throughout the United States. There are many great laws and regulations that help in the vetting process of accepting refugees that can live in the United States as responsible citizens. Contrary to the allegedly false accusations of some officials in the Trump Administration that refugees and immigration into the United States have increased the level of terrorism and crime, data has shown that most refugees become responsible citizens and make worthwhile contributions to their new communities and country (Encyclopedia of the American Foreign Relations, 2017; Balkan and Tumen, 2016; Center for American Progress, 2015; Tumen, 2016).

However, historically, we have seen that lack of proper regulations, lack of proper enforcement of rules, and lack of sufficient "checks and balances" can increase some individuals' temptations toward unethical and corrupt practices (Levin and Thomas, 2013). For example, recently, an official with the U.S. Embassy in Vietnam admitted that he rubber-stamped nearly 500 visitor visas to the United States in exchange for more than $\$ 3$ million in bribes, which he then used to buy nine properties overseas. The official named Michael T.Sestak, 42, pleaded guilty, telling a federal judge he was part of a conspiracy - along with five others from the U.S. and Vietnam - to commit bribery and visa fraud. Because of Sestak's "selfish greed", nearly 500 foreign nationals were able to enter the United States without the proper screening. The cost for getting visa ranged as much as $\$ 70,000$ per application; and the entire scheme generated at least $\$ 9,780,000$. Reports have stated that Sestak personally received about a third of that, which he laundered through China into Thailand (Levin and Thomas, 2013; Wochit News, 2015). This case shows that Vietnamese refugees and immigrants were not the individuals committing fraud and illegal acts, but rather American officials who expected to be bribed for granting of visas into the United States. Of course, there are certain structures and regulations that assist in doing criminal background checks to ascertain what activities prospective candidates might have been involved with in their past jobs and experiences (Cavico, Mujtaba, and Muffler, 2014). However, past behavior does not always guarantee legal and ethical actions in the future. Nonetheless, it is disappointing to hear of more and more civil servants being involved in widespread corruption across the globe. "Broken institutions and corrupt officials fuel inequality and exploitation - keeping wealth in the hands of an elite few and trapping many more in poverty" (Ugaz, 2015: 2). As such, political structures and regulatory structures need to keep up and change accordingly to reduce such crimes and illegal activities.

The political economy in many countries has been completely changed in the late 1980s and early 1990s. Over the last decade, about 87 countries have been classified as "free" countries, where people enjoy political and civil rights. Countries in Eastern Europe, Latin America, as well as South Africa are newer democracies. About 
60 countries (31\%) are considered "partly free" nations; and 47 countries have been classified as a not free at all. Despite their transition toward a democratic system, some commentators still see Russia as a "not free" nation. One of the main factors in the development of more free nations is the advent of information and communication technologies, such as smartphones, tablets, computers, television, and social media, which technology has reduced each government's ability to control access to uncensored information (Hill, 2013: 83). The extent of freedom in a country is primarily based on its political and regulatory system.

A country's regularly and political system consists of a set of principles of government in a nation that emphasizes either collectivism or individualism and thus either practices a democratic or a totalitarian way of governing and leading. There are many components that make up a country's regulatory and political structure. Research shows that the concept of "collectivism" refers to a political system that stresses the primacy of collective or group goals over individual desires and objectives (Hill, 2013). Those individuals and nations with a collectivism approach believe that government control for the greater good is what is beneficial for any society. This system promotes "the greater good" believing that the collective needs of a society as a whole should take precedence over individual needs or goals. This collectivist mentality harkens back to the ethical philosophy of Utilitarianism, propounded by the $18^{\text {th }}$ century English philosophers Jeremy Bentham and John Stuart Mill. All people get "counted" in the Utilitarian calculus, said Bentham and Mill, and all people's pleasures and pains are registered, measured, and weighed, but if an action produces the "greater good" for society as a whole, then the action is a moral one regardless of any harm to a minority of people. The "ends justify the means", as the cardinal Utilitarian maxim says (Cavico and Mujtaba, 2009). This type of a utilitarian-premised society is often associated with Socialism, which is a way of organizing a society where major industries are owned and controlled by the government rather than by individual people and companies. Socialism is based on the belief that government-owned or controlled businesses' will do better because they are not profit-motivated and, thereby, should able to act in a socially responsible manner toward all stakeholders, including employees, ultimately making jobs and wages fair while also benefiting local communities and society as a whole.

Socialism. Socialism can be in the form of Communism or Social Democracy. China has traditionally practiced Communism but that country slowly has moved away from strict adherence to the Communist ideology, at least from an economic standpoint, toward a mixed-economy. Social democracy is practiced in a number of European nations, especially the Scandinavian ones, as well as in South Asia, notably in India. One "downside" to collectivism or state-owned businesses for the purposes of production is that quality and innovation can suffer due to a lack of rigorous competitiveness. When people or businesses are protected from market competition by their government-granted monopoly position in the industry and/or guaranteed government financial support, many firms and individuals tend to become increasingly inefficient (Hill, 2013). The consequent poor performance in many instances has resulted in driving some countries and some public firms toward privatization. Privatization can also be a precursor to individualism.

Individualism. Individualism refers to a philosophy that a country's citizens should have total freedom to pursue their own economic and political dreams as they see appropriate. In other words, individual freedom and the welfare of society can be best served by letting people pursue their own economic self-interest, as opposed to some collective body, such as the government. This political and economic philosophy harkens back to the $18^{\text {th }}$ Century English economist, Adam Smith, and his "invisible hand" theory. As such, this philosophy promotes a free market economy which allows individuals the right to pursue their own business interests based their own unique knowledge and skills and on supply and demand. The result will be that people will benefit, their lives will be enriched, more and better products and services will be available, and society will ultimately benefit, and all will be accomplished by the "invisible hand" with little to no interference of a government entity being involved or in control (Cavico and Mujtaba, 2009). Nations with this philosophy tend to teach others that an individual's needs and interest should outweigh, or be equal to, the needs and interest of the majority of the collective public. Individualism's origins can be witnessed from the history of Great Britain (England), Holland (the Netherlands) and other Western countries over the past five centuries. A philosophical foundation for individualism was provided by the $18^{\text {th }}$ century German philosopher Immanuel Kant who stated that in determining the morality of an action one must disregard consequences, even overall good consequences for society, and instead concentrate on the form of an action which, in order to be moral, must treat individual people as worthwhile human beings deserving of dignity and respect.

There clearly are fewer regulations applied to individualism; and as such many believe that this "free market" mentality is a more conducive environment for business, as there is little to no government control. However, there are "downsides" to individualism; there is in particular the potential for abuse, anticompetitive practices, 
and corruption stemming from a lack of government regulation and control. Another specific disadvantage is too much freedom for corporations may tend to lead to gigantic economic entities, highly monopolistic, which can engage in the exploitation of the people, the causation of economic "highs and lows" which can cause market and societal instability, and too much influence, and perhaps power over, government. Many believe that the economic downturn in the U.S. in 2008, caused by the housing "bubble" and subsequent real estate collapse and stock market crash, necessitating a major "bailout" of the banks, was the result of not having enough government regulations and monitoring. Yet others contend that the government was a principal cause of the "bubble" and collapse by promulgating regulations that unduly encouraged, and in some cases forced, banks to make housing loans to people who could not afford the properties or sustain the mortgage payments. As such, one can conclude that there must be a balanced approach in order to have prudent regulations to prevent corruption and abuse but also effective regulations to prevent the further financial and economic distress, which can lead to economic collapse, recessions, depressions, and all producing negative economic and political repercussions for nations around the world (Mujtaba, 2014).

Democracy. Democracy is concerned with a political system in which government is run by the people instead of an authoritarian leader; and government bureaucrats, or more euphemistically called "civil servants," are either directly or indirectly elected representatives of the people in the community or nation (Hill, 2013). The democratic approach is based on the belief that people should be directly involved in the decision-making of how a government is run and how the public's resources are used. Democracy tends to run in parallel with individualism. In a democracy, the people's representatives are selected by the citizens based on independent votes from the community and these individuals form a government to carry out the wishes, needs and wants, of that city, county, or region based upon constitutional law.

Democracy has spread throughout the world over the last 20 years; and this transition is a consequence of the decline of totalitarianism. There are many reasons for the spread of democracy throughout many nation-states. One reason is due to the failure of most totalitarian regimes to deliver economic progress to their populations. Eastern Europe collapsed underneath Communist rule because of the energetic and affluent economies that were being experienced in the West and the declining economic conditions of Communist rule in the East. There are a number of countries or even independent regions (such as the old West Germany, Hong Kong, and Taiwan) whose economies thrived due to a democratic way of governing and leading and adherence to freemarket principles. As such, today, the economic success of many of the newer democracies, such as Poland and the Czech Republic of the former Communist bloc, the Philippines and Taiwan in Asia, and Chile in Latin America, have strengthened the case for democracy as a key component of successful economic advancement (Hill, 2013: 83).

A second reason for the collapse of totalitarian regimes is the advent of the information technology age. The introduction of the intranet and worldwide web along with other communication technologies has most definitely reduced the ability of many country states access to uncensored material. The advent of these virtual technologies has made the world a "smaller place"; and thus has opened many avenues for people's voices to be heard, thereby leading more toward democratic ideals across the globe. In the past several years, we have seen the exponentially increased usage of Facebook, Twitter, asynchronous as well as synchronized virtual communication, and other social media technologies. The growth and widespread influence of such technology were seen when the Egyptian government was replaced, in part due to the initiatives organized by young people who utilized social media as a means to communicate to express their desires for government change as well as to promote, coordinate, and lead their actions.

Some of these advancements politically and economically are due to the increase in the availability of education and the availability of knowledge worldwide. The availability of knowledge has influenced the rise toward democratic restructuring. For example, the democratic reformation of South Korea can be seen, at least partially, due to the result of the advancements in politics and economics. South Korea is one of the most widely-connected countries in the world, where most people are able to quickly and affordably access knowledge in real-time using the Internet and other communication tools and sources.

Furthermore, many countries have moved away from a totalitarian or command regime toward a free marketbased economy in order to enhance the quality of life for their citizens. The United States, Switzerland, Hong Kong, and Taiwan are countries that have experienced significant economic growth by adopting market-based systems. It should be noted that economic freedom does not necessarily always equate with political freedom, as demonstrated by China where free-market reforms, and economically successful ones too, have not yet lead to increased political freedom for the Chinese people. 
A transition economy is considered to be an economic system in a nation that is changing from a centrallyplanned economy toward a free market where entrepreneurship and fair competition is encouraged. Over the last century, India has been seen as an example of a transition economy. After the independence of 1947, India embarked on transitioning toward a mixed economy (capitalism and socialism). Large industries such as auto, chemical, and steel production companies were owned by the government. As a result of the strict rules and regulation, production quotas, and high tariffs, imports were stunted, labor laws created more difficulties, and the country's economy was harmed (Hill, 2013: 88). China and Russia are other examples of transition economies as they attempt to provide fair competition for their citizens through freer markets yet under much more strict government control. The main benefit of the free market is that key components of the economy and growth are driven by the actual demands of consumers and producers, rather than artificial demands imposed on them by the economic plans and dictates of state authorities. Overall, history demonstrates that a democratic political system in the long-run is an essential condition for sustained economic progress.

Totalitarianism. Totalitarianism is a political concept which holds that the citizen should be subject to an absolute state authority and this is in total opposition to a democratic form of government. While decisions can be made quickly by the leaders who are in charge in a totalitarian society, there can also be rampant repression, injustice, and degradation. Ultimately, the people of the community or nation would have little to no influence on rules and regulation. Countries that are under the dictatorship form of a totalitarian regime can include, Cuba, China, Vietnam, Laos, and North Korea. Of course, there is no one specific factor that helps a nation-state to be economically stable and prosperous. Over the last four decades, we can see the continued shift of many countries from totalitarianism or command toward mixed economies and a free-market based economy, as the latter tends to foster more competition, innovation, and entrepreneurship which are considered to be the foundation of the production of wealth, economic growth, and economic and political stability.

Mercantilism. Mainstream economists are unanimous on the idea that trade helps all countries. Countries produce products and services in which they have a comparative advantage and trade for things in which they do not. This approach can allow the total world production to be higher than it otherwise would be. The main goal of mercantilism is to increase a nation's wealth by imposing government regulation concerning all of the nation's commercial interests. The philosophy is that national strength could be maximized by limiting imports via tariffs and maximizing exports. In nations where excessive government regulation is discouraged and frowned upon by the people, mercantilism would not succeed.

The principal tenet of mercantilism is that a country should maintain a trade surplus, even if that means that imports are limited by temporary or excessive government intervention. This policy is no longer valid for many reasons. Foremost, mercantilism is inconsistent with the general notion of modern globalization and interdependent relationship among countries, which are becoming more and more prevalent in the world. A policy of mercantilism can anger potential trade partners because it will exclude their goods from free access to the mercantilist country's markets. This consequence can naturally lead to trade wars among countries. Eventually, a country will find it difficult to export if it imposes oppressive quotas and tariffs on its imports. Furthermore, mercantilism is a bankrupt theory because it hurts the consumers in the mercantilist country due to limited options and higher prices. By denying its consumers access to either "cheaper" goods from other countries or more "sophisticated" goods from abroad, the mercantilist country's ordinary consumers suffer, thereby slowing down its economy.

Therefore, there is no denying the overall importance of political systems. A country's political system drives its economic and legal systems. It is important to first understand a country's political system before making sense of its economic and legal systems. This comprehension is due to the fact that the political system will ultimately shape the country's other systems. In short, a country's political system is its government system and concomitantly its legal system.

\section{Laws and the Legal System}

Regardless of the government form, ultimately it is the legal system of a nation or country, which refers to the rules and laws along with the processes by which the laws are enforced, that regulate people and business's conduct (Cavico and Mujtaba, 2014). The legal system is very important for corruption management as it regulates a country's business practices. The legal system of a country is heavily dependent upon the political system of the nation, and it is also influenced by historical data. In a way, a country's political structure determines the legal blueprint of a country. The common types of legal systems used today are common law, civil law and theocratic law. 
Common law is usually based upon tradition, precedent and customs practiced in the country. The United States and the United Kingdom practice common law, which is a culmination of a country's legal history based upon former cases brought before the courts and by the way laws are interpreted in various situations. This form of law can be more flexible than the other two because of the way the law is interpreted is based upon certain characteristics. Judges have the power to interpret the law and apply it to each case according to its specific characteristics. Judges utilize past cases in rendering decisions on similar cases and because of this laws are able to be altered, clarified or amended. Common law is contract oriented and most often contains lengthy detailed conditions because of the "gray areas" that often times exist. These contracts are used in the enforcement of laws.

A civil law system is based on a detailed set of laws that are organized into codes which govern behavior. This form of law is more structured and less controversial than common law because decisions are based upon specific codes. Judges are forced to make decisions based upon set codes which makes decision making less flexible. Countries such as Germany, France, Japan, and Russia operate by a civil law system. Judges in this type of law system only have the power to apply the law, unlike a common law system where they have the power to both interpret and apply the law based on the situation and precedence. Civil law systems also utilize contracts but that are often times shorter than common law contracts because most issues are covered in the civil codes. These contracts are also in place for the enforcement of civil law much like that of common law. Overall, in the civil law system judges cannot make any changes in civil law, they just simply follow them. Germany, Japan, and Russia are examples of the civil law approach.

A theocratic law system is one in which the laws and expectations are based on religious teachings which should govern all decisions and behaviors. Unlike common and civil laws, a theocratic law is based upon religious morals which is used to rule all aspects of life for individuals, businesses and governments. Some examples of the nations where religious laws are partially or fully utilized can be seen in countries such as Pakistan, Egypt, Saudi Arabia, Afghanistan, and Malaysia. Though these countries govern based upon Islamic religious beliefs there is also a mix of common and civil law mixed in. Overall, most Muslim countries now have the mix of both Islamic law and a common or civil law system. (Hill, 2016: 54). It should also be mentioned that Judaism and Hinduism have also had religious law systems and some communities still follow these systems.

While there might be common law, civil law or theocratic law practiced in a country, often international businesses must work with them and rely on the international community to settle cross-cultural disputes based on established regulations or norms. The issue that often times arises with international trade contract disputes is which countries' law takes precedent. The United Nations Convention on Contracts for the International Sale of Goods (CIGS) was enacted to resolve such issues among individuals, businesses, firms, and countries. According to Hill (2013), the CIGS established a uniform set of rules which governs various aspects of the making of everyday commercial contracts between sellers and buyers from different nations. In the event that these businesses from disputing countries choose to not utilize the CIGS, they can rely on arbitration courts for settling contract disputes.

Overall, we can say that the political system of a country strongly influences its economic and legal systems. Political systems can be categorized as collectivism, individualism, democratic, and totalitarian. A country aiming to be competitive and free of corruption in the global market should aim for individualism and democratic approaches of running their government while protecting property rights. A system that relies on totalitarian and collectivism ideals will isolate itself, which can lead to entropy. Achieving economic development and growth requires countries to shift and transition toward democracy, deregulation, privatization, and adjusting the legal system to protect property rights of both local and global citizens.

Many factors are involved in the economic development of a country. In order to achieve increasing economic development, a country must strive for frequent and consistent growth. Innovation, which happens best with less regulation, is essential for growth within a market. Innovation includes the development of new products, services, procedures, production, and manufacturing. Entrepreneurship is an important factor that drives an economy's growth and goes hand-in-hand with innovation. In order to encourage innovation and entrepreneurship, a market economy without too much regulation is necessary for people to use their creativity for the betterment of society and their own wellbeing. Research has shown that market economies better lend themselves to innovation and freedom for entrepreneurs to branch out and to prosper. Corruption, however, unfortunately emerges as an impediment and hindrance to entrepreneurship and business, particularly when engaging in international business. 


\section{Corruption}

Often it has been said that one needs to "grease the palms" in order to secure business in certain places. Corruption, especially in the form of bribery of government officials, is often acknowledged as an existing reality of doing business globally. A business person doing business globally very well may confront a lower level government official looking for a little "tip" to "grease the wheels" to get certain necessary "paperwork" processed; or the business person may confront a higher-level official looking for a much larger "commission" before he or she "signs off" on a contract with the official's government (Cavico, 2014; Mujtaba, 2014; Cavico and Mujtaba, 2010). There are many laws combatting corruption, particularly bribery. Yet corruption may exist due to the lack of laws or "loose" legal enforcement, usually exacerbated in the latter case by the payment of bribes.

Corruption can be as simple as facilitating and expediting payments which are often small payments to help the process go more smoothly in routine government actions, such as processing custom forms and getting licenses and permits. The preceding type of corruption is characteristically called "petty corruption". Of course, these small payments to obtain a favor can lead to more serious forms of corruption, called "grand corruption". As most U.S. business people know (or should know), the Foreign Corrupt Practices Act (FCPA) is an important U.S. law that criminalizes the payment of bribes to foreign government officials with the purpose of obtaining contracts or retaining business with foreign governments. Specifically, the FCPA criminalizes the transfer of "anything of value" to a foreign government official, directly or indirectly, in order to obtain business (called a "purchase bribe"), to retain business, or to seek an exemption from the host country's laws (called a "variance bribe"). However, there must be a showing of "bad intent" or corrupt motive on the part of the alleged bribe-giver; that is, evidence is required that the intent of the bribe-giver was to wrongfully direct business to his or her firm, which perhaps was not the low bidder on the project, or to wrongfully seek an exemption from the host country's laws (Cavico, 2014; Cavico and Mujtaba, 2010). Although the FCPA is a U.S. law it has "extra-territorial" effect in that it can reach U.S. business people doing business overseas as well as foreign nationals, assuming the U.S. government can obtain jurisdiction over the latter. Moreover, there is an international treaty against bribery, the Organization of Economic Cooperation and Development's (OECD) Convention against Bribery, which treaty parallels the FCPA. Yet whether the signatory nations to the treaty are actively enforcing its anti-bribery provisions, particularly against their own nationals doing business overseas, is another matter indeed (but beyond the scope of this article yet quite suitable for future academic exploration).

Corruption, of course, can occur in a variety of situations and not "merely" in business; and "no society is immune" to it (Hill, 2013). Corruption can have a very negative impact on economic growth. The level of corruption may depend on what the country allows. In addition to the FCPA and the OECD treaty, there are often "local" laws to attempt to reduce the level of corruption within a country; but these laws vary from nation to nation since what is acceptable in one country may be a legal violation in another. Some countries have strict laws that punish violations of the law while some countries have weak laws. In countries where the law is weak and/or enforcement is lax, politicians or those in public office may openly flaunt corruption and thus readily accept bribes and other forms of corruption as "fringe benefit" or "goodwill" gift. Corruption, however, though benefitting certain foreign government officials, will ultimately reduce the rate of economic growth and harm a society. Therefore, a principal government objective should be to resist and punish corruption of any-and-all kinds in order to possibly eliminate such wrongdoing. Policies, rules, regulations, as well as the enforcement of such laws, should place to combat corruption and particularly in the case of bribery, these regulations should impact not "merely" the business person bribe-giver but also the government official bribe-taker.

\section{Regulatory Rationales}

The origins of regulation, whether of the individual or the company, seem to devolve from two fundamental principles of what regulation seeks to achieve: protection of the individual and society at large, which goals can be achieved through the prevention of government power abuse as well as corporate power abuse (Cavico and Mujtaba, 2014). However, this issue is rarely investigated, the act of creating regulations does in itself confer power on the individual or organization monitoring and enforcing the regulated activity, that is, the government regulators themselves; and this power in turn may be abused by government officials seeking certain "favors" in order for a firm to do business or to get business.

However, there is an assumption that without some form of regulation, anarchy and rampant power abuse would occur - this could be viewed as a counterfactual argument as modern society has never been without some form of regulation (Mujtaba, 2014). The founding tenet from which regulation derives is that basically 
unless restricted, individuals and companies will act irresponsibly with no concern other than a selfish egocentric satisfaction. Regulation, by curbing irresponsibility, seeks to make business leaders, executives, and managers more aware of other stakeholders and not "merely" the shareholders or for that matter their own selfaggrandizement; and thus regulation seeks to motivate business people to behave in ways which provide equitable returns to all parties rather than just one or a few.

The twin principles of individual protection and power abuse prevention apply closely the consumer and business segments. Protection is the primary aim for consumers, examples of this could be through regulation such as traffic lights, speed limits, and controls over drug and tobacco usage. Regulation within business seems to be concerned mostly with prevention of power abuse and the establishment of an equalization of the power base between a company and its customers. It is perhaps significant that the OECD describes its corruptions index as a "product market regulation index", thereby suggesting regulation of businesses not only extends to their internal operations but wider, to include the products they produce and the markets they operate in.

There is both historical and contemporaneous evidence of the need for some form of control within a business, and consequently, a lack of control over unfettered business very well may lead to abuse and corruption. Historically, the excesses of the $19^{\text {th }}$ century labor markets and poor conditions for workers culminated along with other factors in the Bolshevik revolution in Russia as well as labor unionization in much of Europe. The poor working and living conditions of the workers were situations that "cried out" for regulation, which was not forthcoming.

In contemporary global business, there are wide variations in both the degree of regulation applicable and the degree to which that regulation is enforced. Many countries and companies turn a "blind eye" to regulation in their desire to attract business through the offer of the lowest possible prices for powerful multinationals - for whom there is little or no regulation once they are outside their domestic jurisdiction, Despite the FCPA and the OECD Convention there is decidedly a difficulty in enforcing corporate regulation across national boundaries. In the absence of any formalized regulation or the enforcement, thereof the sole arbiter is selfregulation based on a moral stance, perhaps formalized in a corporate Code of Ethics, which is hopefully more than mere "window-dressing". Even in an era of Corporate Social Responsibility (CSR) and "sustainability" accountability and auditing, it is the forthright, moral, and brave business person who will object to a too low price supplier, perhaps with an exploitative facility, or question too closely whether national or local regulations have been complied with when a foreign government official is given a nice "commission" (perhaps bribe) to sign off on the company's contract with the official's government. "Let the locals deal with the locals", as the old maxim in international business says. That maxim, perhaps, is the prevailing business view.

Even the biggest companies are not immune from this dystopian vision. Primark, Benetton, Zara and H\&M were among a host of multinationals having garments made at the Bangladeshi factory, which collapsed in April 2013 with the loss of 1,000+ lives. In another business area Walmart, Carrefour and Tesco are among the multinationals inherently complicit in exploitative labor allegations and even slavery involving Vietnamese prawn fishermen. In these cases, and there are many others one might cite, regulation may or may not be available, but regulation certainly was not enforced. Another recent example concerned JP Morgan bank in China where the bank was accused of violating the FCPA by allegedly bribing Chinese government officials to secure very lucrative consulting contracts with large state-run enterprises by hiring the sons and daughters of these government officials. The bank, which ultimately settled with the U.S. government and paid millions in fines, contended that it was "merely" following local customs, creating goodwill, and engaging perhaps in a little legal nepotism; and thus the bank asserted that its intent was not "corrupt". There were no criminal prosecutions of the bank or its personnel either in the U.S. or in China; and the bank obtained very valuable business in China and gained profits many times over the fines paid (Cavico, 2014). So, was the bank's goodwill "gesture" a bribe pursuant to the regulatory scheme of the FCAP? Did the regulation prevent the alleged corruption?

Therefore, as posited by the authors, the relationship between regulatory control and corruption is an important subject to explore. The authors in the next section to this article present the methodology for the analysis here that seeks to examine the relationship between regulation and corruption.

\section{Methodology}

This study used available data from 47 countries to assess the relationship of perceived corruption and regulation. We chose these specific countries due to the convenience of data availability as well as familiarity with them as per the authors' collective personal experiences. The Corruption Perceptions Index (CPI) of the OECD measures the perceived levels of public sector corruption worldwide. The index captures the informed 
views of analysts, businesspeople and experts in countries around the world. The data source of the Index for 2013 was the Transparency International website ${ }^{1}$. The Organization for Economic Co-operation and Development (OECD) Indicators of Product Market Regulation (PMR) are a comprehensive and internationally-comparable set of indicators that measure the degree to which policies promote or inhibit competition in areas of the product market where competition is viable. They measure the economy-wide regulatory and market environments in 34 OECD countries and in another set of non-OECD countries in 2013. They are consistent across time and countries. The indicators cover formal regulations in the following areas: state control of business enterprises, legal and administrative barriers to entrepreneurship, as well as barriers to international trade and investment. Not all data are available for all countries for all years. The source of data for 2013 was the OECD website ${ }^{2}$. Table 1 shows the data collated for this evaluation.

Table 1. Country Product Market Regulation and Corruption Perceptions Index Data

\begin{tabular}{|c|c|c|}
\hline Country & PMR & CPI \\
\hline Australia & 1.29 & 81 \\
\hline Austria & 1.19 & 69 \\
\hline Belgium & 1.39 & 75 \\
\hline Canada & 1.42 & 81 \\
\hline Chile & 1.51 & 71 \\
\hline Czech & 1.39 & 48 \\
\hline Denmark & 1.22 & 91 \\
\hline Estonia & 1.29 & 68 \\
\hline Finland & 1.29 & 89 \\
\hline France & 1.47 & 71 \\
\hline Germany & 1.29 & 78 \\
\hline Greece & 1.74 & 40 \\
\hline Hungary & 1.33 & 54 \\
\hline Iceland & 1.5 & 78 \\
\hline Ireland & 1.45 & 72 \\
\hline Israel & 2.15 & 60 \\
\hline Italy & 1.26 & 43 \\
\hline Japan & 1.41 & 74 \\
\hline Korea & 1.88 & 55 \\
\hline Luxemburg & 1.46 & 80 \\
\hline Mexico & 1.91 & 34 \\
\hline Netherlands & 0.92 & 83 \\
\hline New Zealand & 1.26 & 91 \\
\hline Norway & 1.46 & 86 \\
\hline Poland & 1.65 & 60 \\
\hline Portugal & 1.29 & 62 \\
\hline Slovakian Rep. & 1.29 & 7 \\
\hline Slovenia & 1.7 & 57 \\
\hline Spain & 1.44 & 59 \\
\hline Sweden & 1.52 & 89 \\
\hline Switzerland & 1.5 & 85 \\
\hline Turkey & 2.46 & 50 \\
\hline UK & 1.08 & 76 \\
\hline USA & 1.11 & 73 \\
\hline Brazil & 2.54 & 42 \\
\hline Bulgaria & 1.57 & 41 \\
\hline China & 2.86 & 40 \\
\hline Croatia & 2.08 & 48 \\
\hline Cyprus & 1.65 & 63 \\
\hline India & 3.1 & 36 \\
\hline Indonesia & 2.42 & 32 \\
\hline Latvia & 1.61 & 53 \\
\hline Lithuania & 1.52 & 57 \\
\hline Malta & 1.57 & 56 \\
\hline Romania & 1.69 & 43 \\
\hline Russia & 2.22 & 28 \\
\hline S. Africa & 2.21 & 42 \\
\hline
\end{tabular}

\footnotetext{
${ }^{1}$ http://www.transparency.org/cpi2015 accessed 30th November 2016

2 http://stats.oecd.org/ accessed $30^{\text {th }}$ November 2016
} 
Screening indicated that the dependent variable CPI is normally distributed. Tests for normality were undertaken (Kolmogorov-Smirnov and Shapiro-Wilk tests), see Table 2. It is therefore inferred the distribution for the dependent variable is normal for both these tests $(p>0.05)$. We therefore accept the null hypothesis for both tests:

Ho - Distribution for the variable is no different from a normal distribution.

$H_{1}$ - Distribution for the variable is different from a normal distribution.

Also, the data was found to be homoskedastic (the variance of the errors over the sample is similar).

Table 2. Data Checks and Assessment for CPI v PMR in 2013

\begin{tabular}{|l|c|c|l|}
\hline \multicolumn{1}{|c|}{ Assessment } & \multicolumn{1}{|c|}{$\begin{array}{c}\text { P-value or } \\
\text { observation }\end{array}$} & Value & \multicolumn{1}{c|}{ Conclusion } \\
\hline $\begin{array}{l}\text { Normality CPI: } \\
\text { Kolmogorov-Smirnov } \\
\text { Shapiro-Wilk }\end{array}$ & $>0.05$ & & $\begin{array}{l}\text { Normally distributed } \\
\text { Normally distributed }\end{array}$ \\
\hline $\begin{array}{l}\text { Correlation: } \\
\text { CPI v PMR (and R) }\end{array}$ & $<0.05$ & -0.576 & $\begin{array}{l}\text { Fail to accept Null - Significant negative } \\
\text { correlation }\end{array}$ \\
\hline $\begin{array}{l}\text { Regression Model: } \\
\text { R-squared } \\
\text { Regression Hypothesis }\end{array}$ & $<0.01$ & 0.332 & CPI explained 33.2\% by PMR \\
$\begin{array}{l}\text { Independent variable } \\
\text { coefficient (PMR) }\end{array}$ & $<0.01$ & 100.181 & $\begin{array}{l}\text { Intercept } \\
\text { regression (there is a gradient) }\end{array}$ \\
$\begin{array}{l}\text { Constant } \\
\text { Unstandardized } \\
\text { coefficient (PMR) }\end{array}$ & -24.001 & Value of B for PMR \\
\hline
\end{tabular}

The hypothesis to test is that there is no relationship between Product Market Regulation and Corruption Perceptions Index. In other words, a test of whether there is a significant effect of Country levels of CPI on Country levels of PMR. Table 2 outlines that the variables PMR and CPI are significantly negatively correlated for 2013 ( $\mathrm{p}<0.01)$. We therefore fail to accept the null hypothesis $(\mathrm{Ho})$ :

Ho-There is no correlation between Country PMR and CPI.

$H_{1}-$ There is a correlation between Country PMR and CPI.

The R-square, strength of the relationship, is 0.332 this indicates that the dependent variable data (CPI) is explained $33.2 \%$ by the independent variable (PMR) data for 2013, therefore $66.8 \%$ is not explained by this relationship but may be by other factors. With reliability and validity measures considered appropriate (normality, homoskedasticity) a regression model was developed. We therefore fail to accept the null hypothesis (Ho):

Ho -There is no good regression between Country PMR and CPI $(\beta=0)$.

$H_{1}$-There is a good regression between Country PMR and CPI $(\beta \neq 0)$.

Table 2 shows that there is a good regression between Country PMR and CPI $(\beta \neq 0)$ at the $p<0.01$ level. Therefore, this result is modeled as:

$C P I=100.18-24.001 P M R+\varepsilon$

In this model, the Corruption Perceptions Index is explained 33.2\% by the Product Market Regulation data, Figure 1. 


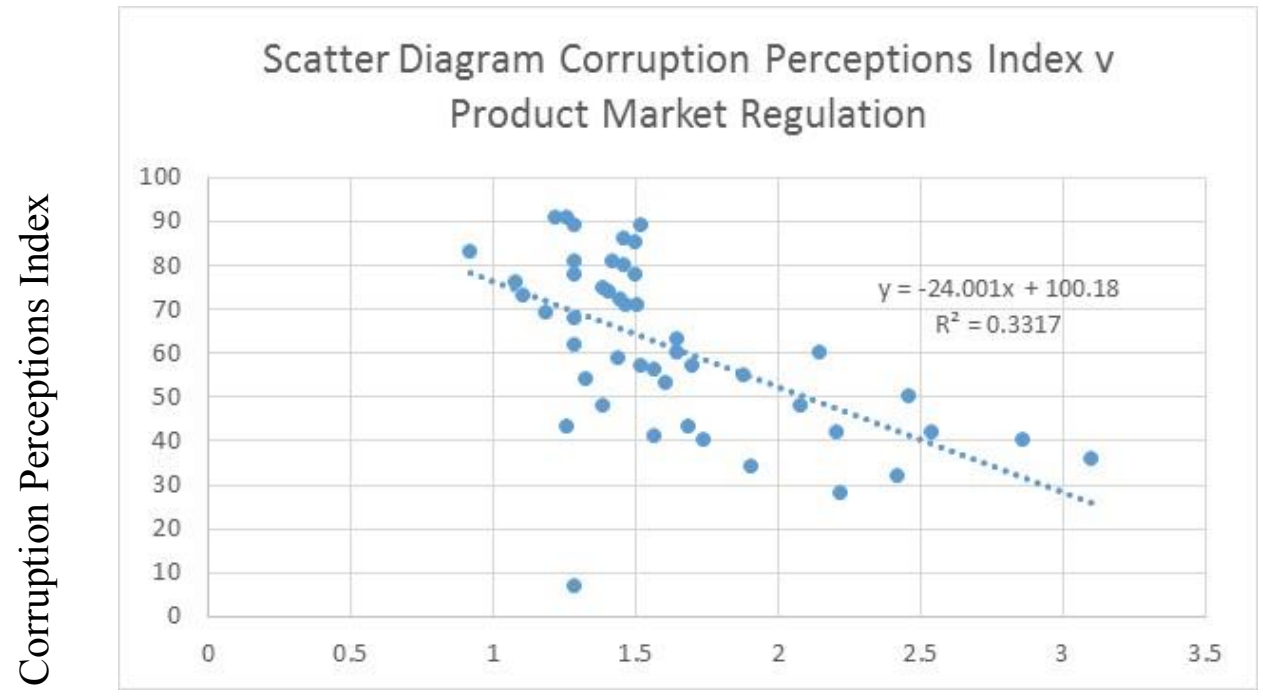

Product Market Regulation

Figure 1. Modeled Corruption Perceptions Index v Product Market Regulation

Overall, the results show that more product market regulation was a significant factor in demonstrating less perceived corruption for the 47 countries selected in 2013. In other words, of those countries evaluated, countries with high levels of regulation had low perceived levels of corruption. The findings are aligned with previous studies which have shown that effective leadership, ethics training, and proper management development workshops can assist organizations and their employees behave more ethically (Ngo, Fisher and Mujtaba, 2014; Tajaddini, Mujtaba and Bandenezhad, 2009; Mujtaba and Sims, 2011; Mujtaba, Tajaddini, and Chen, 2011a; Mujtaba, Tajaddini, and Chen, 2011b; Mujtaba, 2013; Mujtaba and Sims, 2006).

\section{Discussion}

Why might there be a connection between the two apparently disparate concepts, and how might they be linked? An initial intuitive approach might conclude the two variables should be negatively related, that is, more regulation would result in less perceived corruption since regulation is, after all, related, at least in part, with the prevention of corruption. There is a simple appeal to this relationship. One legislates in order to reduce corruption - the typical cause and effect relationship.

In this focused empirical study, the authors demonstrated that more regulation is associated with less perceived corruption. This means that countries with high levels of regulation seem to have low perceived levels of corruption. However, a limitation should be noted in that it may not be the "mere" presence of business regulation which is the key issue, but rather the veracity and zeal with which such regulation is applied and enforced in practice. Yet the data examined herein does not (and cannot) give any sense or measure of the degree to which regulation is enforced and, in particular, whether violations are prosecuted. The data simply disclose the degree to which regulation exists. The degree of enforcement and especially prosecutions, therefore, would be very suitable topics for future academic examination.

Corporate corruption is often a subtle and insidious activity, and not amenable to often "blunt instrument" regulation, which in turn poses the question, can corruption ever be rooted out? What government regulation can do is to create policies, principles, rules, regulations, and frameworks within a society whereby corruption may be investigated and punished. Yet clearly what emerges as a difficult and challenging task is the application of these rules and regulations in practice, particularly their criminal enforcement. It is noticeable that many of the higher regulation/higher corruption countries are in lower GNP segments; and hence it is less likely for these countries to have large expenditure or resources to police business conduct and enforce business regulation. Therefore, ultimately, it may be that this perceived corruption variable is simply a reflection of lower wealth, which factor previous studies (Mujtaba, McClelland, Cavico, Williamson, 2013) have shown is very closely associated inversely with levels of corruption.

Corruption occurs in every country all over the world, regardless of whether they are developed or poor nations (Ugaz, 2015; Mujtaba, Williamson, Cavico, and McClelland, 2013). Unfortunately, corruption is most prevalent in third-world countries where regulations are few, lower level government officials are poorly paid, 
and the enforcement of any regulatory scheme is even more problematic. And, sadly with corruption comes crime and violence which cannot always be easily stopped and prevented since there may be government complicity in the wrongdoing. Institutions and firms that are associated with wrongdoings and unethical practices will have difficulty retaining qualified employees (Udechukwu and Mujtaba, 2007).

Therefore, the authors can say that the "business" of corruption, crime, and bribery can be lucrative for certain foreign government officials. Moreover, it can be a lucrative one for a "big business" that does not obey the law and self-regulate the conduct of its executives, managers, and employees. Businesses can bribe government officials or other businesses for oil, drugs, land, and contracts with the government, which can include major projects, such as building infrastructure related to ports, pipelines, and roads (Shah, 2014). Such corruption increases poverty and societal inequalities by creating in essence "unequal trade" agreements.

Yet laws combatting corruption and bribery do exist. In particular, executives, managers, employees and trainers must be aware that the U.S. Foreign Corrupt Practices Act, which as noted has extraterritorial effect, has made it illegal for American corporations and their employees to bribe foreign officials to obtain business with foreign governments. The U.S. Department of Justice enforces the criminal law aspects of the FCPA. Furthermore, the U.S. Securities and Exchange Commission (SEC) and the Internal Revenue Service (IRS) also find these types of bribery transactions illegal as they tend to put law-abiding businesses at a competitive disadvantage as well as eventually harm the host country and society. In cases where corporations or their employees or agents get caught breaking such laws, they can be heavily fined and even criminally prosecuted and sentenced to imprisonment for their misdeed. As such, business leaders and investors, especially institutional investors, using sensible industry or corporate regulations, should make it clear to executives, managers, and employees that they must not be engaged in any form of corruption, bribery, or unethical business practices. Rather, a company should act in a legal, moral, ethical, and socially responsible manner as that "high road", coupled with good sound business decisions, will lead ultimately to success and sustainable success for the company and all its stakeholders, including society as a whole.

Of course, political and governmental leaders have a huge role in making sure regulations are focused on reducing and eliminating the temptation of individuals for bribery and other illegal acts. By creating, implementing and enforcing sensible regulations, governments can "ensure real and systemic reform - starting with freeing judiciaries from political influences and creating better regional cooperation between law enforcement to stop the corrupt hiding in different jurisdictions...people need to keep their pressure on leaders and demand the accountable, well-functioning institutions they deserve" (Salas, 2015: 9). If we are serious about making corruption a "thing of the past", then governments all over the world "need to take bold steps to ensure rule of law is the reality for everyone. Prosecuting corruption will restore faith among people who no longer believe in the institutions that are supposed to protect them. Transparency and accountability must go hand in hand when tackling corruption" (Uwimana, 2015: 17).

Of course, "reversing corruption is clearly not solely down to governments, but they're the ones with the largest role and the power to create enabling environments for others" (Plipat, 2015: 11). While regulations must be a critical component of the solution, one knows that government alone cannot solve corruption problems alone; as such, the entire "civil society must have the space to be a serious partner in the fight against corruption" (Zughayar, 2015: 15).

\section{Conclusion}

As empirically tested in this study, countries with high levels of regulation exhibit lower perceived levels of corruption. The conclusion in this study is that to prevent corporate power abuse business regulations must be in place, and these regulations must equally be policed and enforced. Moreover, non-domestically-based purchasers must be willing to "step away" from government officials as well as suppliers not adhering to the regulations. It is in their long-term self-interest and that of their stakeholders to do so, the authors submit. As such, government officials and corporate executives should feel comfortable in creating ethical and sensible policies, rules, and regulations that govern the conduct of their employees toward making legal, moral, ethical, and socially responsible decisions.

The authors, in closing, want to acknowledge that the perceived level of corruption is only a "perception", and consequently not the actual level of corruption. As such, testing the perception of corruption is not equal to actual corruption. It also should be noted that another limitation of this study is that it is based on only 47 countries; and as such, each might have diverse legal, cultural, and historical norms, which could influence the level of corruption and/or the degree of regulatory enforcement. Future studies should include data from 
clusters of more countries and regions with uniform structures and cultural norms. The relationship between corruption and regulations can be very complex as many variables are involved in any analysis. Therefore, any results should not be generalized as absolutes. Nevertheless, the authors trust that they have made a modest contribution to expanding the body of knowledge regarding the relationship of regulation to corruption; and they hope that other researchers will be able to build upon this research and thus further expand the work in this very important academic and practical subject matter. Preventing corruption is critical to the equitable economic development and thus essential to peace and prosperity for business, government, people, and global society.

\section{References}

1. Anand, G., \& Kumar, H. (2016, Novemeber 8). Narendra Modi Bans India's Largest Currency Bills in Bid to Cut Corruption. The New York Times, Retrieved from: http://www.nytimes.com/2016/11/09/business/india-bans-largest-currency-bills-for-now-n-bid-to-cutcorruption.html.

2. Balkan, B., \& Tumen, S. (2016). Immigration and prices: Quasi-experimental evidence from Syrian refugees in turkey. Journal of Population Economics, 29(3), 657-686.

3. Barker, J. M. (2016, April 1). FBAR compliance. Journal of Accountancy. Retrieved from: http://www.journalofaccountancy.com/issues/2016/apr/fbar-compliance.html.

4. Cavico, F. J. and Mujtaba, B. G. (2015). JP Morgan Recruitment Practices in China: Legal Networking or Illegal Bribery. Open Law and Ethics Journal, 1, 30-37.

5. Cavico, F. J. and Mujtaba, B. G. (2014). Legal Challenges for the Global Manager and Entrepreneur (Second Edition). Dubuque, Iowa: Kendall Hunt Publishing Company.

6. Cavico, Frank J. (2014). Corporate Social Responsibility and Leadership. Florida: ILEAD Academy.

7. Cavico, F. J., Mujtaba, B. G., and Muffler, S. C. (2014). Criminal Background Checks in Employment: An Unfolding Legal Quandary for Employers. Journal of Law and Criminal Justice, 2(1), 41-103.

8. Cavico, F. J. and Mujtaba, B. G. (2010). Baksheesh or Bribe: Payment to Government Officials and the Foreign Corrupt Practices Act. Journal of Business Studies Quarterly, 2(1), 83-105.

9. Cavico, F. J. and Mujtaba, B. G. (2009). Business Ethics: The Moral Foundation for Effective Leadership, Management, and Entrepreneurship ( $2^{\text {nd }}$ Edition). New York: Pearson Education.

10.Center for American Progress (2015). Vietnamese Factsheet. Retrieved 2/10/2017 from: https://cdn.americanprogress.org/wp-content/uploads/2015/04/AAPI-Vietnamese-factsheet.pdf.

11.Drug Enforcement Agency (2016, August 11). DEA Announces Actions Related to Marijuana and Industrial Hemp. Retrieved from drug enforcement administration: DEA Announces Actions Related to Marijuana and Industrial Hemp.

12.Encyclopedia of the American Foreign Relations (2017). The Vietnam War and Its Impact - Refugees and "boat people". Retrieved 2/10/2017 from: http://www.americanforeignrelations.com/O-W/The-VietnamWar-and-Its-Impact-Refugees-and-boat-people.html.

13.Goodman, P., Gough, N., Wee, S., \& Ewig, J. (2017, January 25). Trump's Tough Trade Talk Could Damage American Factories. The New York Times. Retrieved from: https://www.nytimes.com/2016/12/02/business/economy/trump-manufacturing-jobs-world-tradechina.html.

14.Hill, C. W. (2013). International business: Competing in the global marketplace (9th ed). New York, NY: McGraw-Hill Companies.

15.Huang, C., Mujtaba, G. B., Cavico, F., and Sims, R. L. (2006). Ethics and Executives: A Cross-Cultural Comparison of Japan, Taiwan, and the United States. International Business and Economics Research Journal, 5(7), 9-22.

16.Ikwukananne, I. I, and Mujtaba, B. G (2013). An Institutional and Architecture Based View of Corruption in Nigeria: An Analysis of a Developing Economy's Formal and Informal Structures. Journal of Business Studies Quarterly, 4(4), 230-239.

17.Levine, Mike and Thomas, Pierre (Nov. 6, 2013). Embassy Officer Admits Taking \$3M in Bribes for Visas. ABC News. Retrieved on February 10, 2017 from: http://abcnews.go.com/Blotter/embassy-officer-admitstaking-3m-bribes-visas/story?id=20807987

18.Luthans, F. and Doh, J. P. (2015). International Management: Culture, Strategy, and Behavior (9th ed.). New York, NY: McGraw-Hill.

19.Mujtaba, B. G. (2014). Managerial Skills and Practices for Global Leadership. ILEAD Academy: Florida. 
20.Mujtaba, B.G. (2013). Ethnic Diversity, Distrust and Corruption in Afghanistan: Reflections on the Creation of an Inclusive Culture. Equality, Diversity and Inclusion: An International Journal, 32(3), 245-261.

21.Mujtaba, B. G., Cavico, F. J. and Senathip, T. (2016). Managing Stereotypes toward American Muslims in the Modern Workplace through Legal Training, Diversity Assessments and Audits. Journal of Human Resources Management and Labor Studies, 4(1), 1-45.

22.Mujtaba, B. G., Williamson, P., Cavico, F. J., and McClelland, B. (2013). Managing the link between Bribery and Wealth based on Corruption Perception Index (CPI) and Gross National Product (GNP) per Capita. Journal of Management Policy and Practice, 14(3), 100-115.

23.Mujtaba, B. G., McClelland, B., Cavico, F. J., Williamson, P. (2013). A Study of Bribery and Wealth in the ASEAN Community Based on the Corruption Perception Index Scores and GNP per Capita. International Journal of Management, IT and Engineering, 3(1), 576-597.

24.Mujtaba, B. G. and Sims, R. (2011). Gender differences in managerial attitudes towards unearned privilege and favoritism in the retail sector. Employee Responsibilities and Rights Journal, 23(3), 205-217.

25.Mujtaba, B. G., Tajaddini, R. and Chen, L. Y. (2011a). Business Ethics Perceptions of Public and Private Sector Iranians. Journal of Business Ethics, 104(3), 433-447.

26.Mujtaba, B. G., Tajaddini, R., and Chen, L. Y. (2011b). Perceptions of Ethics by Public and Private Sector Iranians. Asian Journal of Business and Management Sciences, 1(2), 104-118.

27.Mujtaba, B. G. and Sims, R.L. (2006). Socializing Retail Employees in Ethical Values: The Effectiveness of the Formal versus Informal Methods. Journal of Business and Psychology, 21(2), 261-272.

28.Ngo, P. T., Fisher, G., and Mujtaba, B. G. (2014). Ethical decision-making of banking and finance professionals and students. Asian Journal of Business Ethics, 3(2), 141-153.

29. Office of National Drug Control. (2012, Feb 7). Marijuana Resource Center. Retrieved from The White House: https://www.whitehouse.gov/ondcp/marijuanainfo.

30.Plipat, Srirak (2015). Corruption Perceptions Index 2015. Transparency International. Retrieved on February 10, 2017 from: www.transparency.org/cpi.

31.ProCon (2016, Novemeber 9). 28 Legal Medical Marijuana States and DC. Retrieved from ProCon.Org: http://medicalmarijuana.procon.org/view.resource.php?resourceID=000881.

32.ProCon.org (2016, November 9). 28 Legal Medical Marijuana States and DC. Retrieved from ProCon.org: http://medicalmarijuana.procon.org/view.resource.php?resourceID=000881.

33.Salas, Alejandro (2015). Corruption Perceptions Index 2015. Transparency International. Retrieved on February 10, 2017 from: www.transparency.org/cpi.

34.Shah, A. (2014, September 4). Corruption. Retrieved January 27, 2017 from: http://www.globalissues.org/article/590/corruption.

35.Singh, R. K. (2016, 11 8). India Abolishes 500 and 1,000 Rupee Notes to Fight Corruption. Retrieved from Bloomberg: http://www.bloomberg.com/news/articles/2016-11-08/india-abolishes-inr500-1-000-rupeenotes-to-fight-corruption.

36.Tajaddini, R., Mujtaba, B. G., and Bandenezhad, M. (2009). Management Skills of Iranians: a Comparison of Technical, Human and Conceptual Differences based on Gender, Age and Longevity in Management Ranks. Labour and Management in Development, 10(1), 1-18.

37.Tumen, S. (2016). The economic impact of Syrian refugees on host countries: Quasi-experimental evidence from turkey. The American Economic Review, 106(5), 456-460.

38.UBS (2016). Global capabilities. Retrieved from UBS AG: https://www.ubs.com/global/en.html.

39.Udechukwu, I. I. and Mujtaba, B. G. (2007). Determining the probability that an employee will stay or leave the organization: a mathematical and theoretical model for organizations. Human Resource Development Review, 6(2), 164-184.

40.Ugaz, Jose (2015). Not one single country, anywhere in the world, is corruption free. In Corruption Perceptions Index 2015. Transparency International. Retrieved on February 10, 2017 from: www.transparency.org/cpi.

41.Uwimana, Chantal (2015). Corruption Perceptions Index 2015. Transparency International. Retrieved on February 10, 2017 from: www.transparency.org/cpi.

42.Zughayar, Ghada (2015). Corruption Perceptions Index 2015. Transparency International. Retrieved on February 10, 2017 from: www.transparency.org/cpi.

43.Wochit News (August 15, 2015). U.S. Diplomat Gets Five Years for Vietnam-U.S. Visa Scheme. YouTube link: https://www.youtube.com/watch?v=cJselZBaTnc.

44.Wood , R. W. (2016, October 19). Beware More FBAR And FATCA Reporting Changes. Retrieved from Forbes: http://www.forbes.com/sites/robertwood/2016/10/19/beware-more-fbar-and-fatca-reportingchanges/\#26e7248d1119. 